\title{
LARGE BARROWS IN EAST LITHUANIA: A MYSTERY YET TO REVEAL
}

\section{LAURYNAS KURILA*}

Lithuanian Institute of History, Kražių St 5, LT-01108 Vilnius, Lithuania

\section{Keywords}

East Lithuania, large barrows, burial, social status, energy expenditure, dominance, prestige

\begin{abstract}
In the context of moderate external variations of East Lithuanian Barrow culture barrows, ones of exceptional diameters and shapes stand out. These are low trapezoid-shaped cross-section mounds, and some are even more complex structures consisting of banks and ditches. Eleven large barrows are known in six cemeteries, all located in extensive cemetery concentrations, along the right bank of the River Neris, and on the left bank of the River Žeimena and in the lakes region to the north of it. This location suggests their significance on a level above a single community. None have yet been excavated, but the stone kerbs, the setting of the barrows in the cemeteries, and the typological and AMS radiocarbon dates from the excavated nearby mounds point to the Migration period, the 5th century being their most probable dating.

The amount of labour invested in building large barrows is evidence of mourners' exclusive mortuary behaviour. In agreement with the concept of energy expenditure in burial, this signals the idiosyncratic status of the deceased. Excavation data from other cemeteries does, however, disprove the idea that we should implicitly restrict great energy expenditure to the highest military elite. The dual model of social hierarchy in social psychology argues that status may be attained through either dominance or prestige. Dominance-based status is expected to force high involvement in burial by power and superiority, which is possible in societies with developed status inheritance, while a prestige-based one is decided by specific social roles, personal achievement, and respect. In a barbarian society, which balanced between chiefdom and big-man type social systems, both were interrelated.
\end{abstract}

\section{Introduction}

Above-ground level burial constructions, barrows, tumuli, cairns, etc, once dominated the cultural landscape all over Europe and elsewhere. Their vast diversity in shape can hardly allow any all-embracing classification (see e.g. Grinsell 1953; Pronin 1981; Johnson 2015, pp. 81-118). Due to regional and chronological differences in burial customs across almost all continents, and from the Neolithic to the Viking Age, the very concept of a barrow is closer to a generalisation than to a definition.

In the Lithuanian and Baltic milieu, with rather rare Neolithic and Bronze Age exceptions (Merkevičius 2016;
Randsborg et al., 2016), burial in barrows was an Iron Age (Roman period to Viking Age) phenomenon. Within this defined area and period, only minor differences in barrow constructions exist, barrow forms being generally rather uniform. Regionally, barrows differ mostly in the use of stones: mounds covered by or entirely built of stones in Sudovian-Jatvingian culture (Bitner-Wróblewska 2010, pp. 152-155; Bliujienè 2016), those enclosed by stone kerbs in northern Lithuania and southern Latvia (Vasks 2001, pp. 217-223; Michelbertas 2016), and in east Lithuania in the Roman period and Migration period (Kurila 2016), or without any stone constructions in the latter territory ( $\mathrm{Ku}-$ rila 2016) and in Latgale (Radiņš 1999, pp. 35-52) in the

\footnotetext{
*E-mail: laurynas.kurila@istorija.lt
} 
Viking Age. Other variables are the manner of burial (inhumation or cremation) and the number of internments, ranging from single burials to collective, long-term family or community ones. The common shape of Baltic barrows is a low semi-sphere, from three to 20 metres in diameter, and up to two metres high. There are several long barrows in eastern Latvia, but even though their ethnic attribution has long been a subject for speculation (e.g. Ligi 1993; Lebedev 1994; Tvauri 2007), one certain thing is that they are not intrinsic to the Baltic world, just as Slavonic burial constructions sopkas and zhalniks are not.

The relationship between the size of barrows and the status of those entombed in them has been postulated since the dawn of Lithuanian archaeology (Tyszkiewicz 1850, p. 51; Pokrovskii 1895, p. 207), just as it has elsewhere. This hypothesis, supported by a good many examples, such as Sutton Hoo in England (Carver 1998) and Chorna Mohyla in Ukraine (Rybakov 1949) (not to speak of the monumental mortuary structures of ancient civilisations), has never been refuted. It was, however, not before the so-called energy expenditure model was proposed by the pioneers of the New Archaeology (Tainter 1978, pp. 125-128) that it acquired a solid theoretical background. The idea of a direct link between the measurable effort put into internment rituals and the status of the deceased had been criticised (Brown 1981, p. 29; Wason 1994, pp. 76-80; Carr 1995, pp. 178-180), but it was never disproven as conflicting with empirical data. It also found its adherents in Lithuania (e.g. Kurila 2009a, p. 160; Bliujienè 2013, p. 152).

Not all energy expended in burial rituals leaves archaeological traces, and the whole burial process should certainly not be viewed from the energy expenditure perspective. Speaking about the size of barrows, it is obvious that it is equivalent to the number of working hours and the involvement of the community, which would theoretically suggest a collective rather than individual (or family) interest in the expression of the deceased's social status. The archaeological image of this symbolic, ideological, and social background, however, cannot be more than hypothesised. Attempts have been made to refer to the mean sizes of barrows, and did not yield random results (Kurila 2009a, pp. 164, 171-172), but too many factors, such as the degree of the mound's preservation, chronological change and regional differences, need to be considered while following this course.

While moderate inequality in barrow size and shape within a statistical 'norm' may not be of special interest, variations extending far beyond what can be called a standard deserve much more attention, as a possible mirror of something fairly different to a couple of spare hands or a spare day for building a larger barrow. Here, several east Lithuanian barrows of exceptional diameter and uncharacteristic shape stand out from the whole of the
Baltic burial domain. The concept of 'a large barrow' is applied not to all those of above-average dimensions (mounds of 20 metres in diameter and/or two or three metres high are not uncommon in east Lithuania), but instead to those with very specific external features. These barrows, first described by Vladimir Kashirskii (1907, pp. 3-4), later drew only minor attention from scholars (Zabiela 1996, p. 44; Kurila 2011, pp. 147-148; 2016, pp. 198-199; Kuncevičius et al., 2012, p. 26; Bliujienè et al., 2017, pp. 122123). Their oneness was stressed, but the debate ended on the simple question of whether they were indeed barrows (Zabiela 1992, p. 21), or on the hypothesis that the Pavajuonis-Rèkučiai barrows served as a place for the eternal rest of the defenders of the nearby defensive installation (Girininkas 2007, pp. 355-356). They are discussed for the first time in more detail in this paper, and with special reference to their chronology and probable social implications.

\section{The occurrence and the appearance of the barrows}

The large barrows discussed are so far known in six barrow cemeteries (Fig. 1), situated in two different parts of the East Lithuanian Barrow culture range. The DailidèsArdiškis II and Grabijolai-Žemaitiškiai II barrow cemeteries (both in the Širvintos district) lie on the right bank of the middle reaches of the River Neris, where, within a narrow buffer from the river, there is an area with a concentration of barrow cemeteries. The sites are nine kilometres from each other as the crow flies, or 12 kilometres along a stream, the space in which Kernave, the notable ancient centre, lies.

Liūlinè II, Sudota and Paduobè-Šaltaliūnè III barrow cemeteries (all in the Švenčionys district), and PavajuonisRèkučiai barrow cemetery (Ignalina district), are located in a huge and extremely dense range of cemeteries, which stretches along the left bank of the River Žeimena into the environs of lakes Kretuonas, Vajuonis, Žeimenys, Lūšiai, and others. Liūlinė II, Sudota and Paduobè-Šaltaliūnè III barrow cemeteries, being only 0.5 to one kilometre apart, are segments of a large barrow cemetery group in the southern part of this range, exclusively on the left bank. It consists of about 20 sites, and now totals nearly 600 mounds. Pavajuonis-Rèkučiai barrow cemetery lies 20 kilometres north of Paduobè-Šaltaliūnė III, in an even larger concentration of barrow cemeteries, situated in the lakes region of the headwaters of the Žeimena. It encompasses about 30 individual cemeteries, over 1,100 mounds altogether. Both cemetery concentrations are separated by a gap of only six kilometres, where the town of Švenčionèliai is situated, which is probably responsible for the absence of barrows in this section. 


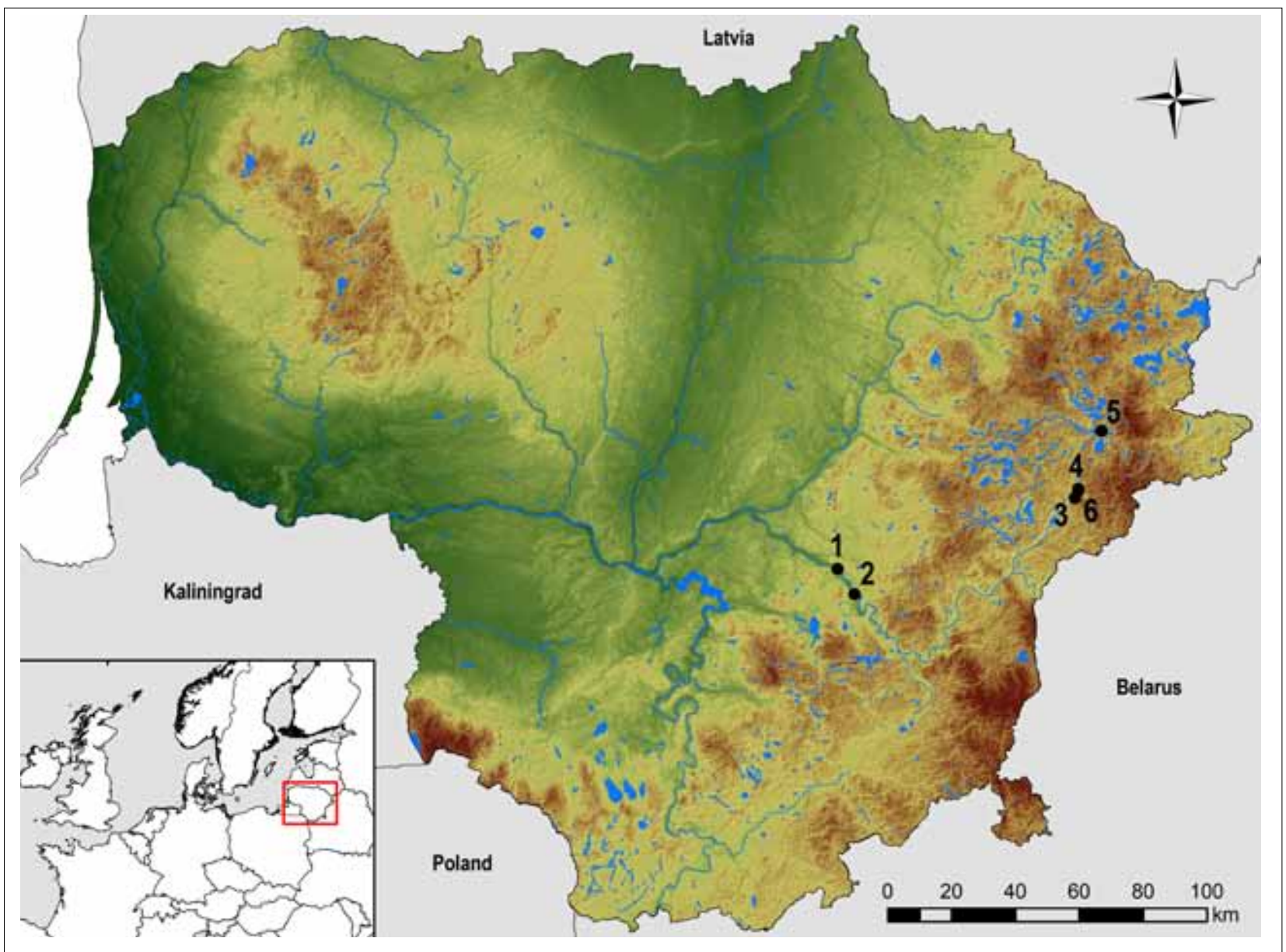

Figure 1. The barrow cemeteries discussed in the study: 1. Dailidès-Ardiškis II barrow cemetery; 2. Grabijolai-Žemaitiškiai II barrow cemetery; 3. Liūlinè II barrow cemetery; 4. Paduobè-Šaltaliūnė III barrow cemetery; 5 . Pavajuonis-Rèkučiai barrow cemetery; 6. Sudota barrow cemetery (map by L. Kurila).

The discussed barrows are distinguished not only by their exceptional diameters, but also by the untypical flat trapezoid cross-section, and some of them by the remains of ditches, flat circular earth banks, and central 'mounds' on the top.

Dailidès-Ardiškis II is a small cemetery of two mounds in the middle of a three-kilometre-long chain of barrows on the upper terrace of the River Neris. Barrow 1 (Figs. 2.1;3) was called by the locals 'the King's Grave' (in Lithuanian, Karaliaus kapas), which derives from an oral tradition that 'a French king' was buried in it (Valstybès 1935, p. 255), a clear allusion to the march of the Grande Armée in 1812. It is 25 (N-S) by 26 (W-E) metres in diameter, and up to 1.5 metres high. A shallow ditch or row of pits encloses the west and northwest feet of the mound, and it is documented to have previously had a stone kerb (Valstybès 1935 , p. 255) of which only one stone can now be found on the west slope. The top of the mound is flat, partly disturbed by old wind-blown trees or amateur excavators. The contours of four to six pits (from $2 \times 2$ to $5 \times 3 \mathrm{~m}$ ) are barely visible on its edges. The original construction seems to have been a regular pit circle surrounding the nine-by-nine-metre central part.

Grabijolai-Žemaitiškiai II cemetery is part of a complex of several settlements and barrow groups scattered in a bend in the River Neris on its upper terrace, around a glaciokarstic hollow called 'the Wolves Pit' (in Lithuanian, Vilku duobè). The latter is shrouded in stories of hidden money, a collapsed tunnel, and soldiers who dug it while burying their comrades in the nearby barrows (Vaitkevičius 2006, p. 57). The cemetery consists of 75 mounds. The largest, barrow 24 (Figs. 2.2; 4), lies on the cemetery's western border, near the slope to the river's lower terrace, surrounded to the north and southeast by other larger barrows. It is distinguished by its diameter of $37(\mathrm{~N}-\mathrm{S})$ by 36 (W-E) metres, and is 1.5 to two metres high, depending on the variations of the contiguous relief. The barrow lacks a ditch around it; there is a barely noticeable five to six-metre-wide deeper zone from which sand was taken for the mound. In the northwest part of the barrow, three old pits are dug in a row from the centre to the slope. These are possibly the traces of old amateur excavations. Two 
stones lie on the surface of the ground in this place, most likely parts of a disturbed kerb. The top of the barrow is flat, and only slightly uneven, due to centuries-old growing and falling trees.

Liūlinè II cemetery consists of only three barrows, of which barrow 3 is the largest in the above-mentioned barrow cemetery cluster south of Švenčionèliai (Figs. 2.3; 5). Its diameter is $36(\mathrm{~N}-\mathrm{S})$ by $37(\mathrm{~W}-\mathrm{E})$ metres, and its height is 1.7 to two metres, being slightly higher on the northwest side. On the west, north and east sides, a shallow three to five-metre-wide ditch surrounds the mound, with two gaps on the northwest and northeast sides. On the southeast side, the ditch could have been disturbed by the road nearby. The generally flat top part of the mound is of complex construction, the original image of which is difficult to characterise. At the very centre, there is a five by four-metre and 0.5-metre-deep pit, surrounded on every side by a four to six-metre-wide low bank, which forms the central 'mound' up to 0.5 metres high (on the other hand, it could have been formed by grave robbers digging a huge pit and casting the sand around it). The whole central construction is encircled by a three to four-metre-wide shallow ditch, and outside it by another three-metre-wide low bank, which reaches the edge of the barrow's upper part.

Several large barrows lie in the southern part of Sudota cemetery (Fig. 2.6), among about 200 remaining from an even larger burial field (some barrows were excavated in the interwar period [Kaczyński 1963] and later [Semènas 2000; 2002a; 2002b; 2005a; 2005b; 2006]. The area was crossed by the Warsaw-St Petersburg railway line in 1859 , and by the Sariai-Švenčionèliai road, thus probably demolishing many barrows). In turn, this barrow cemetery is part of an even larger group of cemeteries, along with others currently protected under the names of Sudota and Paduobè-Šaltaliūnè. One barrow (Fig. 6.1) on the cemetery's southern border is $31(\mathrm{~N}-\mathrm{S})$ by 33 (W-E) metres in diameter, and about 1.5 metres high. A ditch three metres wide surrounds its foot with a gap on the south side. The top of the mound is flat and even, except for some roughness caused by long-lasting vegetation.

Some of the other barrows in the cemetery are distinguished by their size and low trapezoid shape in cross-section. One of them (Fig. 6.2) is 120 metres northwest of the largest one. It is $29(\mathrm{~N}-\mathrm{S})$ by $26(\mathrm{~W}-\mathrm{E})$ metres in diameter, and 1.6 to 1.8 metres high, and has a two to four-metrewide and up to 0.5 -metre-deep ditch around it, which joins the neighbouring barrows on the west side. The mound's top is flat; however, it is impossible to establish now whether it was even or of a more complex shape in the past. This is due to damage caused probably by old excavations. A pair of two to three-metre-wide trenches going northwest-southeast and northeast-southwest intersect on the top, which is a typical technique of early excavators. We can assume that this was done by the railway engineer van Glazenberg, who probably excavated this cemetery in 1859 at the time of the construction of the WarsawSt Petersburg railway (Tautavichius 1953, p. 24). On the other hand, he is more likely to have excavated on the railway line, which was the main zone of his work, and less likely to have used the then advanced excavation technique of crossing trenches. This is presumably the place where a turn-of-the-century amateur archaeologist worked but failed to leave any record. One stone lies on the southwest slope of the barrow. It probably comes from the disturbed kerb.

The third largest barrow is 25 metres in diameter, 1.2 to 1.5 metres high, and has a characteristic flat top. There are at least 3 more mounds exceeding 20 metres, and of a somewhat similar shape. These are surronded by ditches with gaps. They form an oblong group extending from north to south.

Barrow 30 in Paduobè-Šaltaliūnè III barrow cemetery (Figs. $2.4 ; 7$ ) also corresponds with the concept of a large barrow. The cemetery itself contained over 70 barrows prior to excavation (Steponaitis 2012), and is part of a larger burial area together with other Paduobè-Šaltaliūnè and Sudota cemeteries. The barrow has a diameter of 25 $(\mathrm{N}-\mathrm{S})$ by $26(\mathrm{~W}-\mathrm{E})$ metres, and a height of 1.5 to two metres. A shallow two to three-metre-wide ditch surrounds it, except for a small gap on the west side, and where it is disturbed or joins the adjacent barrows. The mound's top is flat, only one two by three-metre pit has been dug on its eastern part, and three other small pits in an arch on its southwest-south edge. These may be traces of some initial constructions, as well as of later damage.

In Pavajuonis-Rèkučiai barrow cemetery (Fig. 2.5), at least four barrows fulfil the concept of the large barrow. They are situated in a group in the southwest part of the cemetery, which consists of 76 mounds in total scattered on both sides of the ancient road called by the locals 'the German road' (in Lithuanian, Vokiečiakelis). One of them, barrow 61 (Fig. 8.1), is the largest not only in the cemetery but also in Lithuania, and probably in all of the Balt region. Its diameter is $40(\mathrm{~N}-\mathrm{S})$ by 41 (W-E) metres, and its height is 1.5 metres at the edges, and two metres in the central part. On the northwest-north-northeast sides, it is surrounded by a two to three-metre-wide shallow ditch with two or three obscure gaps. The mound's shape resembles a flat platform more than a barrow, and its construction is complex. A 3.5 to four-metre-wide and 0.2 to 0.3 -metredeep ditch girdles the whole top part, and inside it stands the flat central 'mound' $19-20(\mathrm{~N}-\mathrm{S})$ by 21 (W-E) metres in diameter and 0.5 to 0.7 metres high. Its surface is even, except for roughness caused by natural processes. 

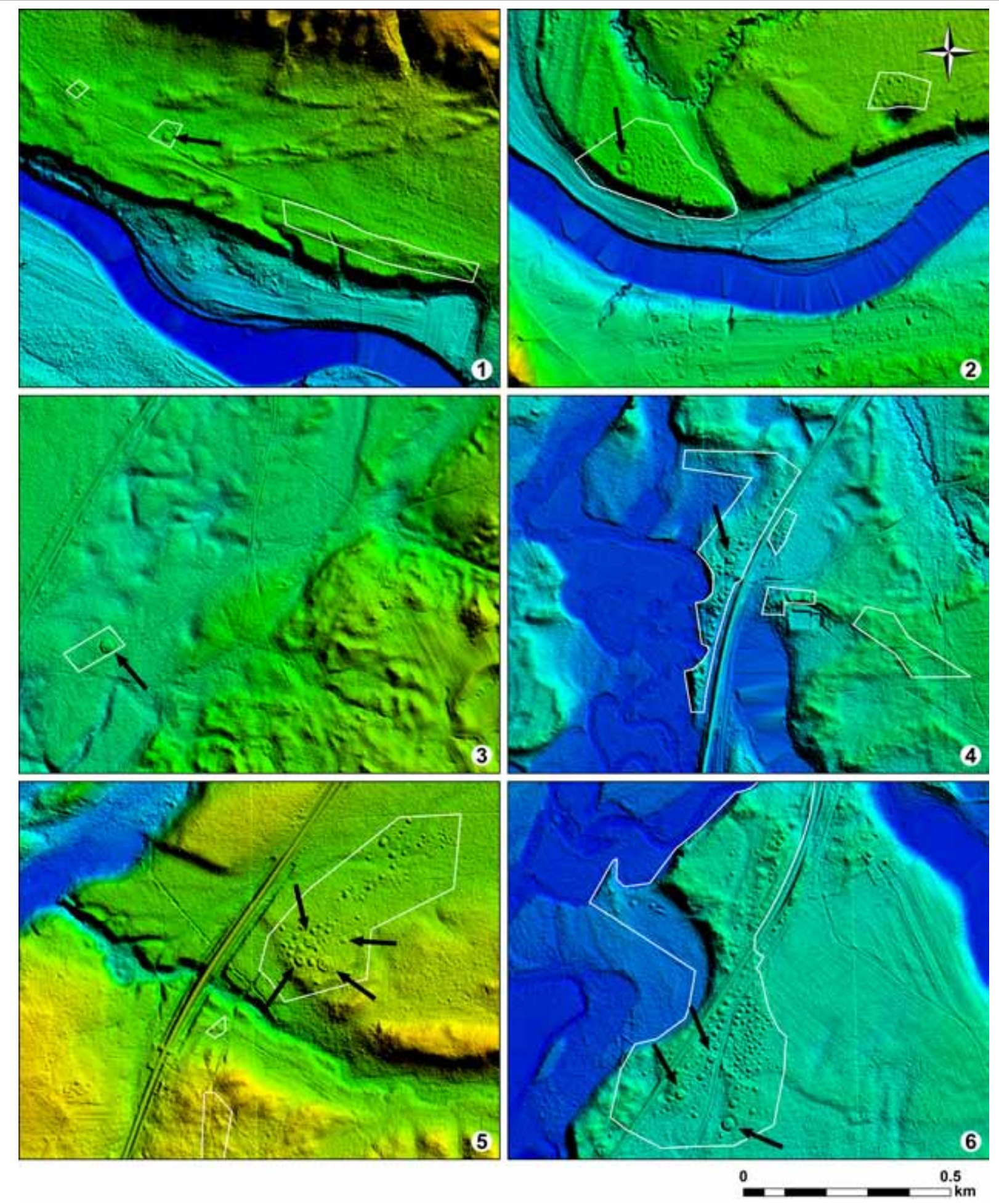

Figure 2. Large barrows (marked by arrows), based on LiDAR data: 1. Dailidės-Ardiškis II barrow cemetery; 2. GrabijolaiŽemaitiškiai II barrow cemetery; 3. Liūlinè II barrow cemetery; 4. Paduobè-Šaltaliūnė III barrow cemetery; 5. Pavajuonis-Rèkučiai barrow cemetery; 6 . Sudota barrow cemetery (protected barrow cemetery territories in white) (maps by L. Kurila). 


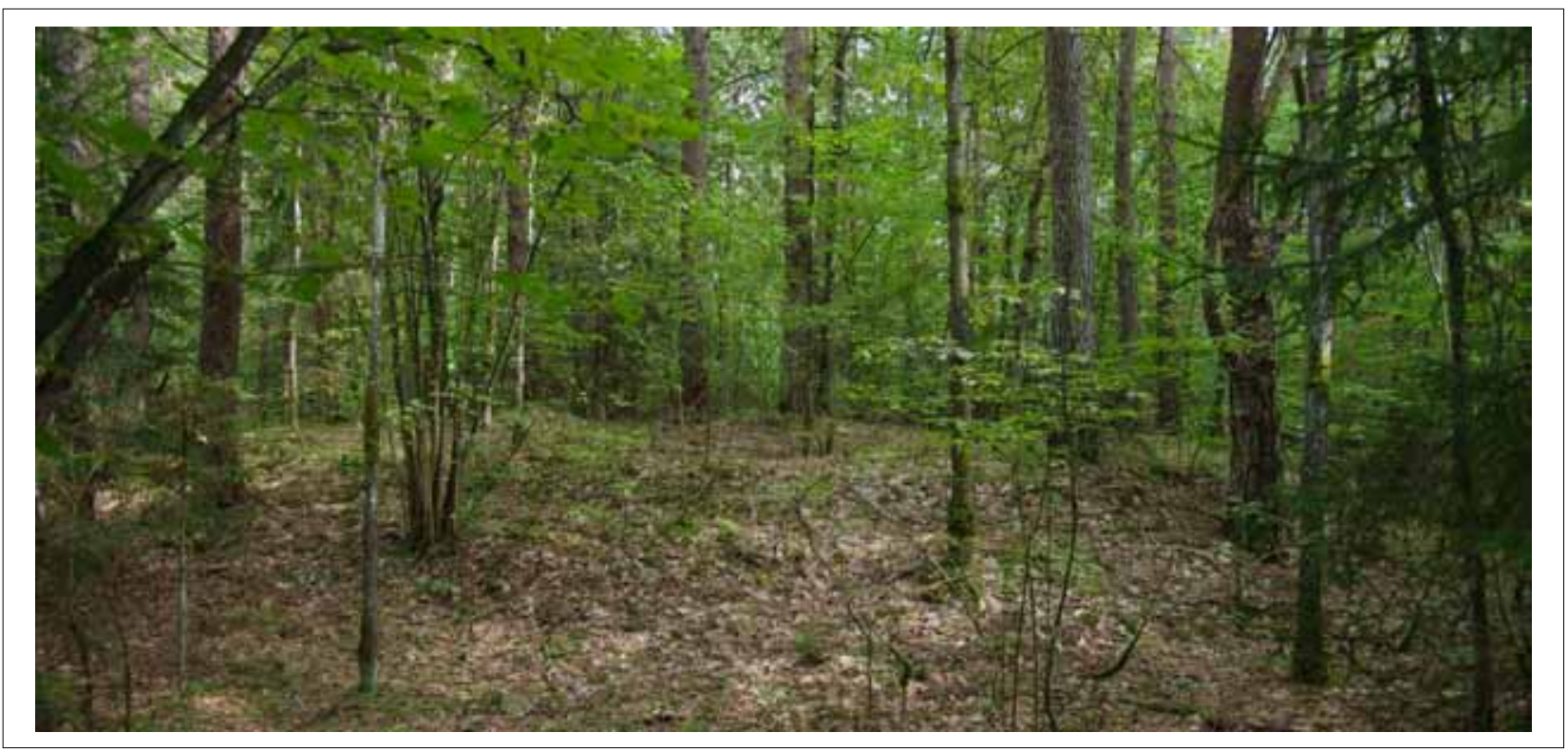

Figure 3. Dailidès-Ardiškis II barrow ('the King's Grave') (photograph by L. Kurila, 2019).

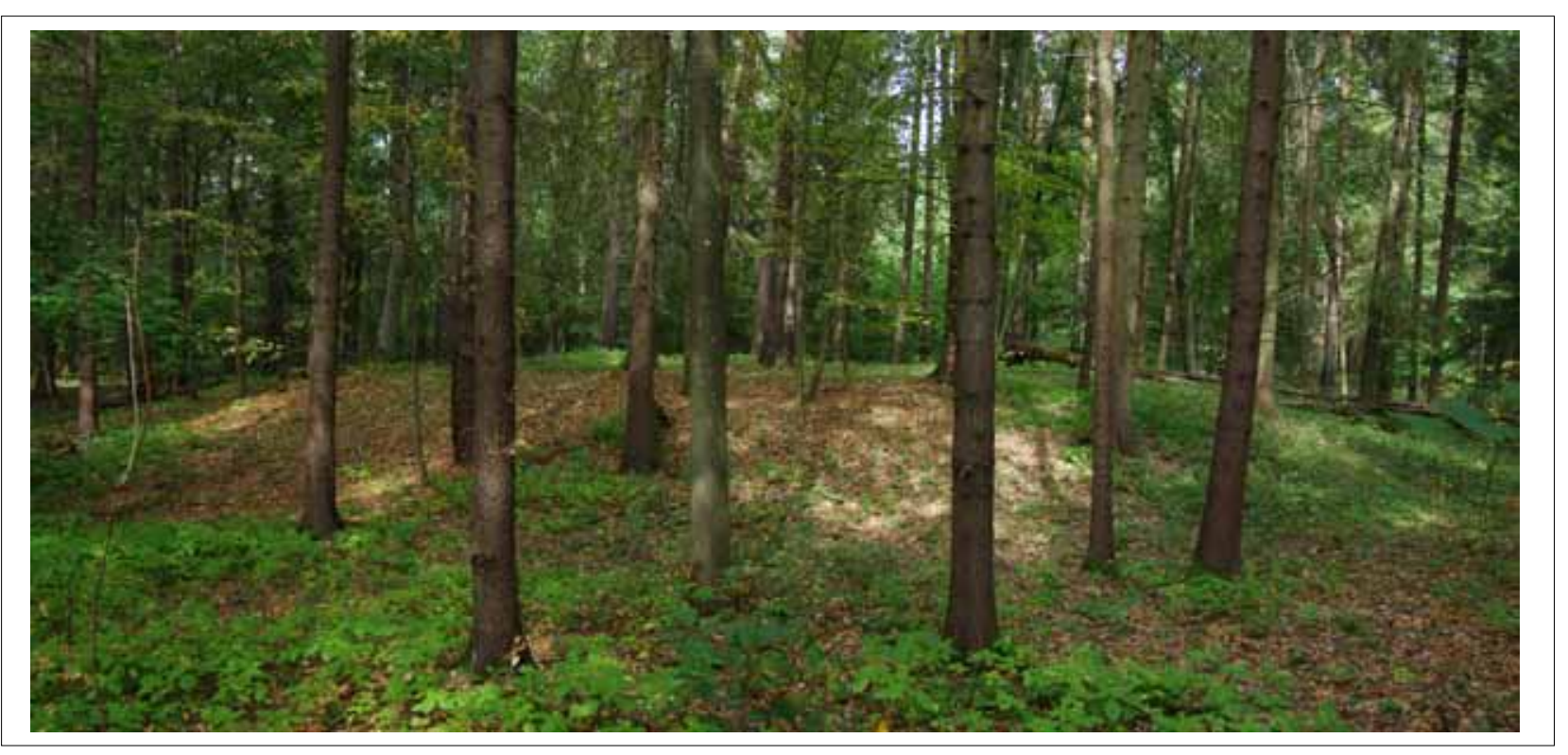

Figure 4. Grabijolai-Žemaitiškiai II barrow (photograph by L. Kurila, 2019).

Kashirskii (1907, pp. 3-4) notes that the barrow showed signs of excavations in his time.

Another, barrow 59 (Fig. 8.2), is to the west of the first one, separated by another rather large but typical mound. It is 29 metres (N-S and W-E) in diameter, and 1.5 to 1.7 metres high. No evident traces of a ditch can be seen around its slopes, except for the surroundings being lowered when building the barrow. A large pit, about five metres in size and up to 1.2 metres deep, has been dug in the centre, and the sand dumped around it. This seems to be a recent dis- turbance rather than an original construction element. An early 20th-century manuscript, however, describes its fairly complex shape as a 'mound' on the barrow's top, near to its centre about 6.5 metres in diameter and 0.9 metres high, and a bank 0.7 metres high surrounding the edges of the barrow's top. Several stones were then visible on the slopes (Kashirskii 1907, p. 3). It seems that the barrow suffered damage after Kashirskii's visit.

Barrow 70 (Fig. 8.3) lies northwest of the largest one. Its diameter is 30 metres (N-S and $\mathrm{W}-\mathrm{E})$, and its height is 


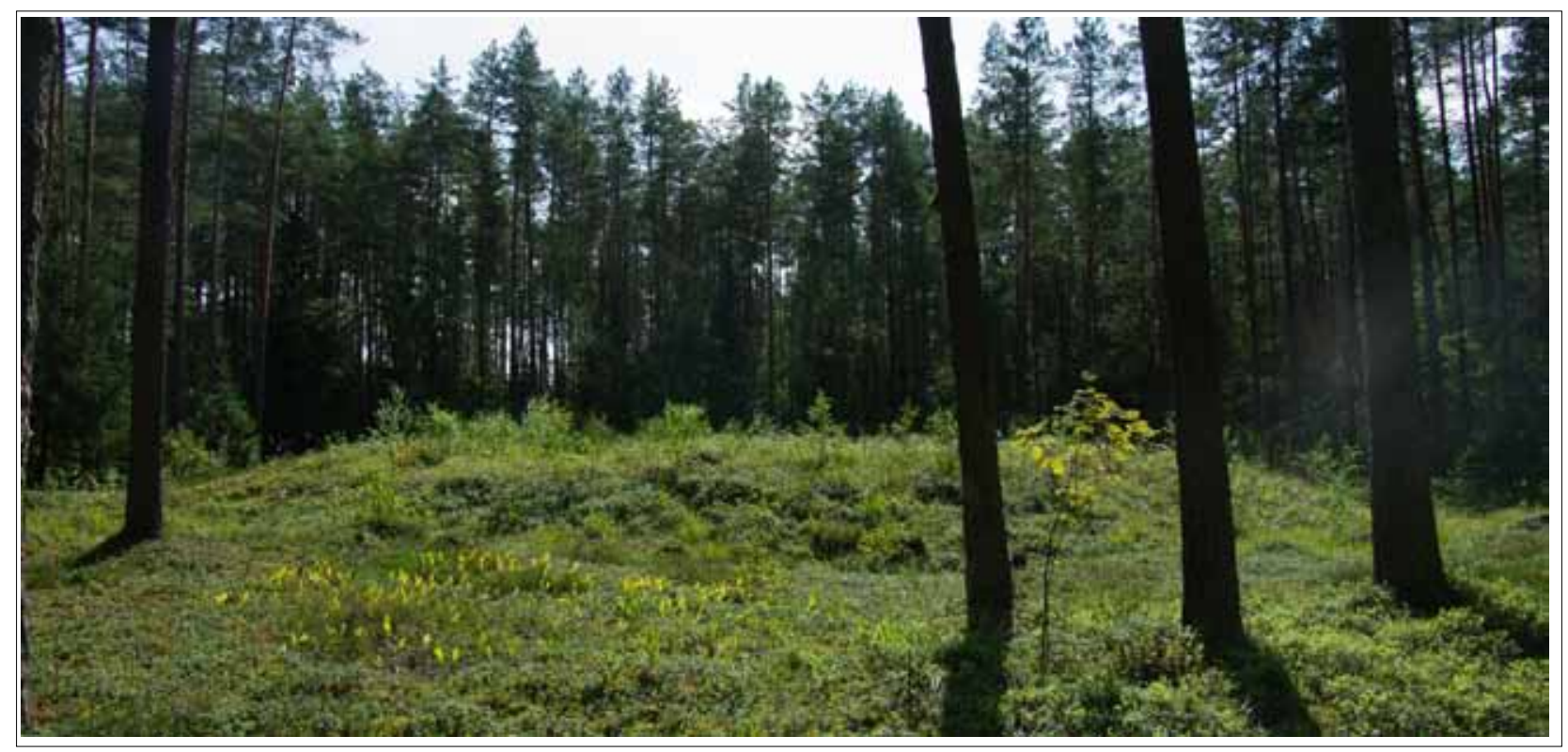

Figure 5. Liūlinè II barrow (photograph by L. Kurila, 2019).

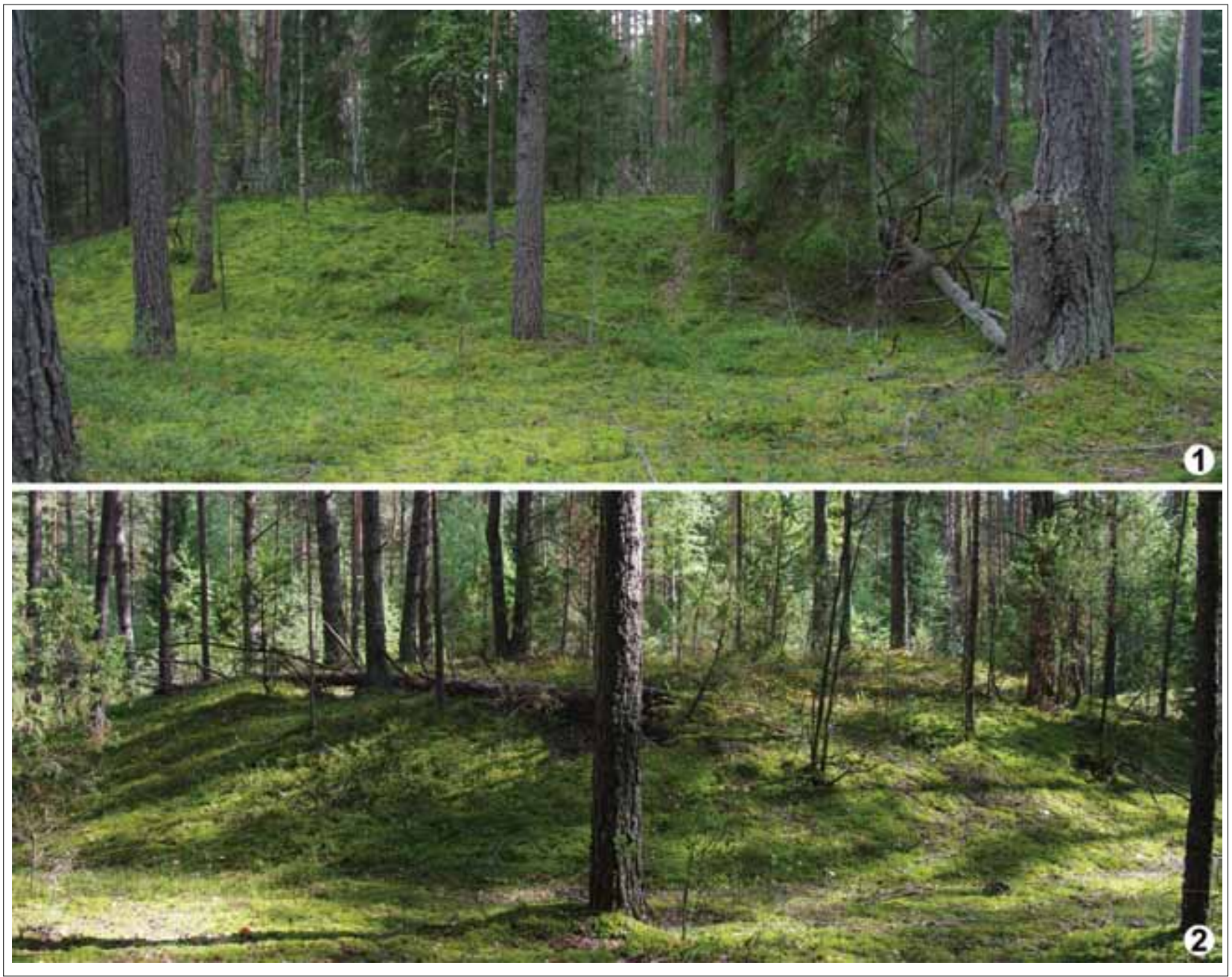

Figure 6. The Sudota barrows (photographs by L. Kurila, 2019). 


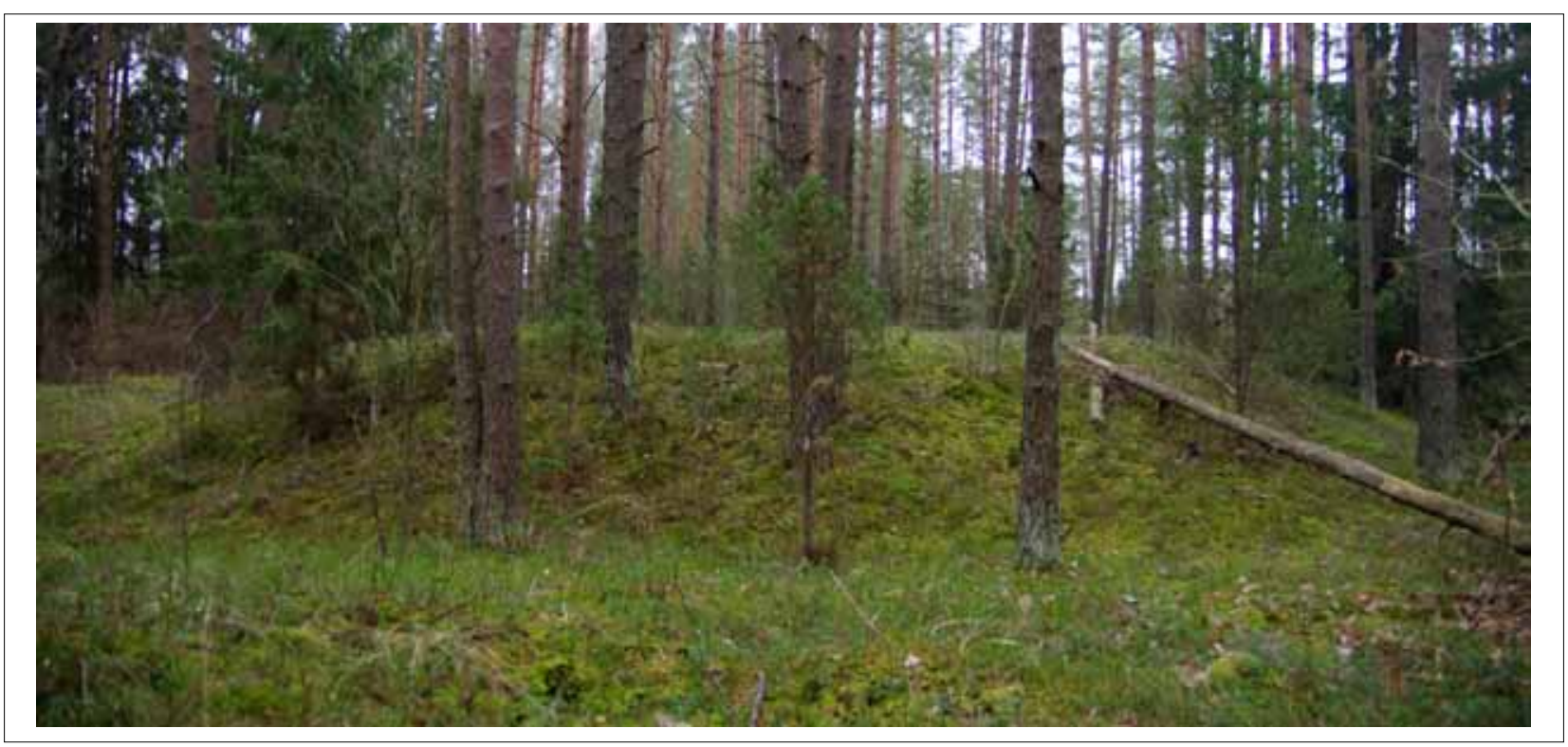

Figure 7. Paduobė-Šaltaliūnė III barrow (photograph by L. Kurila, 2019).

about 1.5 metres. Traces of ditches around it are almost invisible, as in the above-mentioned one. The central part has been disturbed by digging a pit six by five metres in size, and up to one metre deep, and casting the sand around. On the north, northwest, west and south periphery of the mound's top, contours of ditches 2.5 to 3.5 metres wide, and up to 0.3 metres deep, are noticeable, which probably surrounded the mound's central part, in some places forming a double circle. Kashirskii (1907, p. 3) describes the barrow as having an even surface, only partly disturbed by excavations, so the pit is the result of later activity. The barrow was also very recently damaged by a wind-blown tree. The brief observation of this place yielded neither finds nor bones.

The smallest of the large ones is barrow 67 (Fig. 8.4), distinguished not by its exceptional size but by its pronounced shape. It is about 60 metres east of the first three. It is a flat construction 20 metres $(\mathrm{N}-\mathrm{S}$ and $\mathrm{W}-\mathrm{E})$ in diameter, and overall 0.8 to one metre high. Shallow two-metrewide ditches are visible only on the north and east slopes. The barrow's top part is an embossed system of ditches and banks. It is surrounded at the edges by a 1.5 to twometre-wide and 0.2-metre-deep ditch, which has gaps on the northwest and southeast sides. In its inner part, a bank three metres wide and 0.4 metres high encircles a two-metre-wide and 0.4-metre-deep pit in the centre. Kashirskii (1907, p. 4) considered the central pit to be the result of amateur excavations which destroyed the central 'mound'. This hypothesis should not be rejected, but considering the pit's and the bank's regular shape, neither should the probability of them being the original construction.
Several more barrows of uncharacteristically large dimensions ( 21 to 24 metres in diameter and up to two metres high) and somewhat similar in their shape to those discussed can be found in other barrow cemeteries: Pabradè, Kirdeikiškè, Paduobė-Šaltaliūnè II and Kretuonai. All these sites are located in the region of the left bank of the River Žeimena.

\section{Chronology}

None of the large barrows have been excavated, and those described above are very unlikely to be excavated in the near future. This is not only due to the amount of resources required, but also because of the heritage protection policy to preserve the most unique archaeological objects untouched. Therefore, the discussion on chronology may proceed only by referring to fragmentary or indirect evidence.

The exterior view of barrows is not a proper indication of their chronology. However, the stone kerbs, which are in some cases documented, or isolated stones still lying on their slopes, do add some clarity. The practice of encircling mounds with stones prevailed in east Lithuania for centuries, but it declined at the beginning of the last quarter of the 1st millennium AD. Hence, this may be assumed to be the upper chronological boundary of the discussed barrows.

Another criterion may be the arrangement of the barrows in cemeteries. All the large barrows are in close proximity to other ones, and within larger barrow groups, with the 

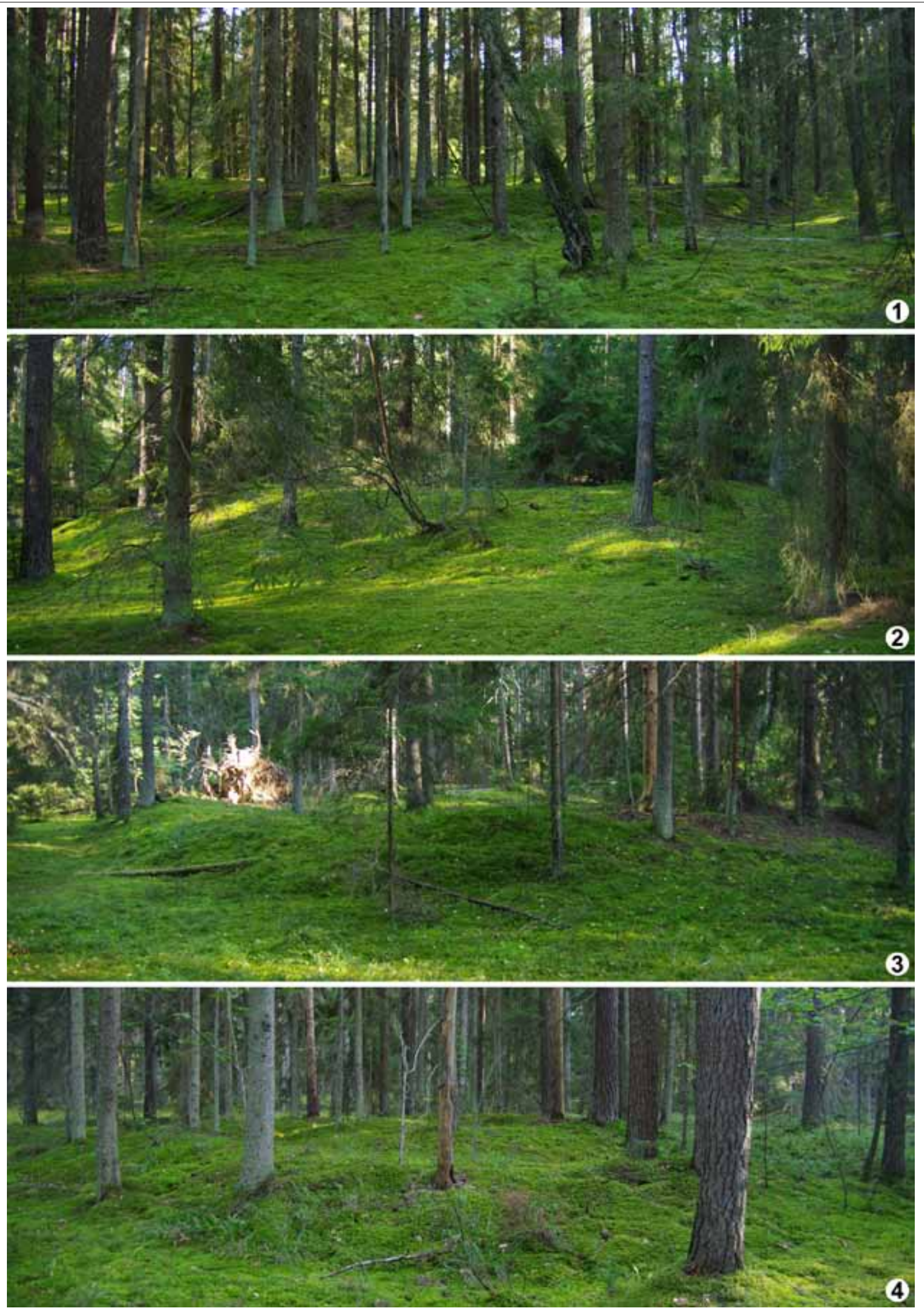

Figure 8. The Pavajuonis-Rèkučiai barrows (photographs by L. Kurila, 2019). 
only exceptions being at Dailidès-Ardiškis II and Liūlinè II. In Grabijolai-Žemaitiškiai II, the large barrow 24 lies at the very western periphery of the cemetery, near the slope of the terrace. This would theoretically allow us to consider it one of the earliest or one of the latest in the cemetery, if we presume that its development was systematic from the centre to the periphery, or from one side to another. The same can be said about the two largest barrows in Sudota, and about three out of four in Pavajuonis-Rèkučiai. The rest of the large barrows in Sudota, the one in Paduobè-Šaltaliūnè III, and the fourth one in Pavajuonis-Rèkučiai, are more or less surrounded by smaller barrows. This supports the assumption that the large barrows are earlier than the surrounding ones, since, considering the density of the barrows, there would hardly have been enough space for a mound of such a size to be built in the late stage of the cemetery.

A third way of indirect dating is the data from excavations of neighbouring barrows, which is seldom sufficiently reliable, especially for large long-used cemeteries, and fairly distant places of excavations. In some sases, reference can be made to AMS radiocarbon dates (Table 1; see also $\mathrm{Ku}$ rila 2015).

In Grabijolai-Žemaitiškiai II, four barrows were excavated in the northern, northeast and eastern parts of the cemetery, or opposite the largest barrow 24 (Luchtanas 2002; 2005a; 2005b; 2006). The cremations discovered date from the middle or the second half of the 1st millennium AD. Only the one found in barrow 4 contained a set of grave goods with clear typological markers from the turn of the Late Migration period, traditionally dated to ca 450-550 $\mathrm{AD}$; but out of the two AMS radiocarbon dates from the same burial, only one indicates a somewhat similar period, 428-638 cal AD, and the other one points to the Late Roman period-Early Migration period (249-394 cal AD). This disagreement can be explained either by differently manifest old wood effects, or by the unsuccessful collection of samples. As long as neither of the radiocarbon dates has been proven incorrect, misguiding typological dating is also probable, but so far the middle of the 1st millennium $\mathrm{AD}$ is the most convincing date.

The Sudota barrow cemetery has been subject to rather extensive excavations. In 1934, 15 barrows were excavated (Kaczyński 1963). Not all of them were marked on the plan by the archaeologist, but those which were lay on the north and east sides of the cemetery, that is, they were quite far from the largest mounds discussed. The barrows had stone kerbs, and contained cremations that were dated, according to the finds, to the middle and the second half of the 1st millennium AD. It is noteworthy that one of the barrows in the southern part, some 120 to 150 metres northeast of the largest one, was called by the excavator the 'large' (in Polish, wielki) barrow, but without any comment on this term, except for the plan where it is marked with quite a moderate diameter. It contained cremations equipped with items characteristic of the last quarter of the 1st millennium AD.

In 1998-2004, seven more barrows were excavated in the southwest part of the cemetery, the area in the western vicinity of the second-largest barrow (Semenas 2000; 2002a; 2002b; 2005a; 2005b; 2006). Graves were found which contained grave goods dated to the middle and the third quarter of the 1st millennium AD. Of them all, special attention should be paid to a burial from barrow 3 (30), which was located about 50 metres to the west of the large one. The burial contained a set of five weapons together with ornaments, including a silver neck-ring and a crossbow fibula, and a silver gilded buckle of Middle Danube region origin bearing signs of repair (Semènas 2000, p. 198; Bliujienè and Curta 2011, pp. 51-52; Bliujienė et al., 2017, p. 133). The assemblage allows the burial to be dated to the late 5 th or early 6 th century AD.

In the area currently protected under the two names of $\mathrm{Pa}$ duobè-Šaltaliūnè III barrow cemetery and Sudota barrow site (not the above-mentioned Sudota barrow cemetery), 25 barrows or places of disturbed ones were excavated (Merkevičius 1990; Steponaitis 2012). These are clustered

Table 1. AMS radiocarbon dates from the discussed sites.

\begin{tabular}{|l|l|l|l|l|l|l|l|}
\hline \multirow{2}{*}{ Barrow cemetery } & $\begin{array}{l}\text { Barrow/ } \\
\text { grave }\end{array}$ & Sample & Lab code & BP & $\begin{array}{l}\text { cal AD } \\
\mathbf{( 6 8 . 2 \% )}\end{array}$ & $\begin{array}{l}\text { cal AD } \\
\mathbf{( 9 5 . 4 \% )}\end{array}$ & References \\
\hline $\begin{array}{l}\text { Grabijolai- } \\
\text { Žemaitiškiai II }\end{array}$ & $4(69) / 2$ & Cremated bone & Poz-63939 & $1715 \pm 30$ & $259-384$ & $249-394$ & Kurila 2015, Tab. 1 \\
\cline { 2 - 8 } & Cremated bone & FTMC-34-4 & $1507 \pm 37$ & $474-609$ & $428-638$ & \\
\hline $\begin{array}{l}\text { Paduobė- } \\
\text { Šaltaliūnė III }\end{array}$ & $16 / 1$ & Cremated bone & Poz-66017 & $1230 \pm 30$ & $714-867$ & $689-882$ & Kurila 2015, Tab. 1 \\
\cline { 2 - 8 } & $17 / 1$ & Bone (human) & Poz-63950 & $1690 \pm 30$ & $332-397$ & $256-416$ & Kurila 2015, Tab. 1 \\
\cline { 2 - 8 } \\
\hline $\begin{array}{l}\text { Pavajuonis- } \\
\text { Rékučiai }\end{array}$ & $2(11) / 2$ & Booth (horse) & UBA-33204 & $1687 \pm 29$ & $334-398$ & $257-416$ & \\
\hline Sudota & $1 /$ Central & Bone & Poz-63957 & $1805 \pm 30$ & $140-245$ & $129-325$ & Kurila 2015, Tab. 1 \\
\hline
\end{tabular}


on all sides of the largest barrow 30 (Fig. 9). Severe damage to some barrows and a lack of chronological markers do not allow more precise dating than at intervals of several centuries, which, however, fall mainly into the Migration period. Only two inhumations, that of a chieftain interred together with a horse in Paduobė-Šaltaliūnè III barrow 17, and the double male and female burial in Sudota barrow 1 , had precise chronological indicators. In the first one, a massive silver gilded buckle tongue, although the only adornment that survived grave robbers, allows the burial to be dated to the third quarter of the 5th century $\mathrm{AD}$ (Bliujienè and Steponaitis 2009, p. 200; Steponaitis 2012, p. 119). Interestingly, AMS radiocarbon dates of both the human (256-416 cal AD) and the horse (257-416 cal AD) appeared older (a complete match between them denies the probability of the freshwater reservoir effect for the human bone sample). Although the typological and radiocarbon age intervals are not so distant in time, they point to different historical backgrounds, that is, the former to the period after the fall of the Hunnic Empire, and the latter likely to the Hunnic wars or even earlier. This issue has to be reconsidered in the future, and the possibility of substantial corrections to the chronology of the series of artefacts should not be rejected.

The Sudota barrow site barrow 1 reveals a unique burial construction: a male lying at the bottom of a large pit, and a young female above, in the top part of the fill (Merkevicius 1990, p. 55). It is a rare example in east Lithuania of the overlap of two cultural horizons, that of rich female graves accompanied by silver ornaments, and the succeeding horizon of male weapon graves. Another double burial of exactly the same construction found in Pavajuonis-Cegelne barrow II contained similar assemblages, including also a Prague-type crossbow brooch as a good chronological marker (Kurila 2011, pp. 131-136, see also Schulze-Dörrlamm 1986, pp. 600-605). This suggests the junction of the Early and Late Migration periods, that is, the middle of the 5th century AD. The AMS radiocarbon date 264-533 cal AD does not generally conflict with this.

The integrated view of excavation data from around the Paduobè-Šaltaliūne III large barrow 30 allows us to define its likely chronology as not exceeding the Migration period, most probably the decades astride the junction of its early and late stages. Its placement in the very central part of the cemetery also speaks in favour of its dating to the early or middle stage of the burial ground, depending on whether a circular or linear model of the cemetery's development is accepted.

In Pavajuonis-Rèkučiai barrow cemetery, two barrows were excavated, both in the southwest part of the area, near the large ones (Fig. 10). Under barrow 6, a human and horse inhumation was found (Semenas 1996). It had been looted in prehistory, and the absence of datable ar- tefacts does not allow its dating based on criteria other than the chronological horizon of other east Lithuanian Migration period horseman burials, i.e. the second half of the 5 th century (if this is not changed by the radiocarbon dates).

Barrow 11 contained two inhumations of a female and a child (Semenas 1998). Both were given luxurious ornaments, such as silver neck-rings similar to the one found in the Sudota barrow site burial discussed, a silver fibula, bracelets and rings, amber, glass-enamel, and coral bead necklaces, etc. The sets point to the short stage of silveradorned women's graves of the Early Migration period (Bliujiene and Curta 2011, pp. 32-36; Kurila 2016, p. 200), the late 4 th to the first half of the 5 th century, or an even shorter span of time. The AMS radiocarbon date 129-325 cal $\mathrm{AD}$, however, points to the Roman period.

Creating small barrows around or between large ones is a much more convincing scenario than building large mounds in empty spaces left for some reason in an area otherwise densely occupied by barrows. This remark applies to at least two out of the four large barrows. It can therefore be argued that the large barrows are contemporaneous with the surrounding ones, including those excavated, or even earlier.

To conclude, following current chronological schemes, most or possibly all the large barrows discussed date from the Migration period. Although this cannot be proven directly, the corpus of indirect evidence suggests a brief episode of creating barrows of this specific shape and size. Where available, the data from the surrounding barrows indicates the moment of change from the Early to the Late Migration period, restricting the most probable date to the 5 th century.

However, the radiocarbon date from Pavajuonis-Rèkučiai barrow 11 once again reminds us of the frailty of typological sequences. If it does not prove false or biased by the freshwater reservoir effect, it may urge fundamental corrections of the dating not only of the site or several artefact types, but of the whole of the chronological horizon, together with its reference representatives from the Sudota barrow site, Baliuliai, Pavajuonis-Cegelnè, and other cemeteries. The above-mentioned radiocarbon date from the Paduobè-Šaltaliūnè III burial, and possibly that of Grabijolai-Žemaitiškiai II, together with other unexpectedly old dates of warrior burials from Taurapilis, Baliuliai and Peršaukštis-Kasčiukai II (Kurila 2015, Tables 3; 4), also conflict with the mainstream concept of weapon graves as markers of the shift to the Late Migration period in the mid-5th century.

A radiocarbon-prompted revision of Migration period chronology is not the goal of this paper. A larger set of new dates is necessary to assume responsibility for undertaking 


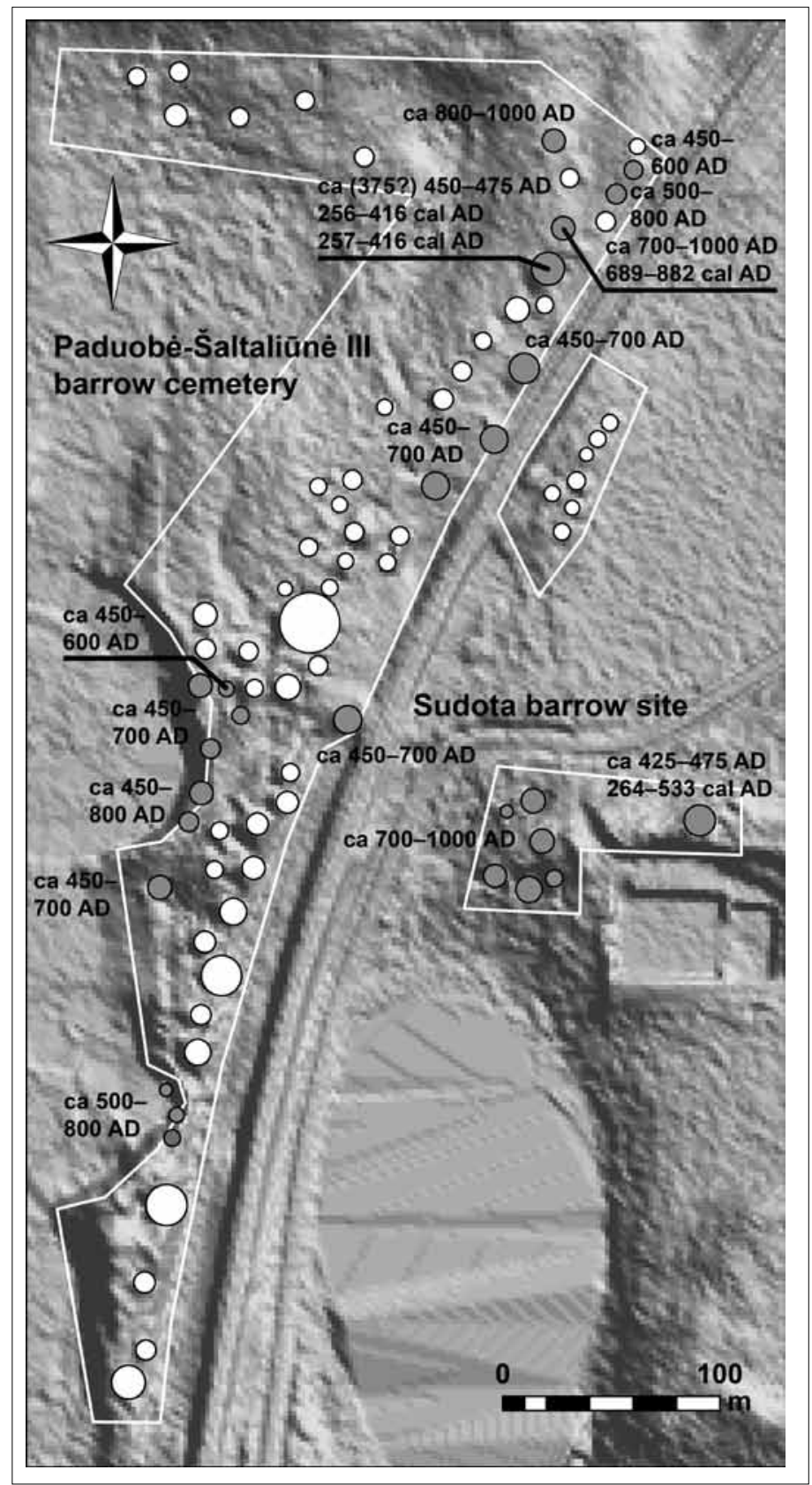

Figure 9. The situation plan and excavated barrows (in grey) in Paduobè-Šaltaliūnè III barrow cemetery and the Sudota barrow site, and their typological and radiocarbon dating (map by L. Kurila, after Steponaitis [2012, p. 114], with additions and spatial corrections made by georeferencing the original plan to the LiDAR image).

this debate. It would probably result in a reconsideration of predominant conceptions, such as an underestimation of the influence of (Sântana de Mureș) Chernyakhov culture on early-stage East Lithuanian Barrow culture, or the engagement of the Balts in distant military campaigns, or migrations before the Hunnic wars. The attractive model of dividing the Migration period in east Lithuania into Early and Late stages, represented by the consequent horizons of the 'silver women' and 'iron men' (Bliujiene 2006, pp. 125-138; Kurila 2016, pp. 199-200), and interpreting the variability of grave good assemblages through change rather than complex horizontal diversities, may also prove unduly simplified. Future discussions encompassing new radiocarbon dates and a reconsideration of the dating of some artefacts (such as the bracelets with thickened terminals and other ornaments found in PavajuonisRèkučiai) may lead to corrections in the chronology of these entire horizons. The dating of the discussed large barrows defined here may go decades back in time, too. They do actually have partial similarities, in terms of their size and shape, with some of those excavated in Poland, at Lübsow/Lubieszewo (Schuster 2010), Pilgramsdorf/Pielgrzymowo (Lau 2014), and in several Wielbark culture barrow cemeteries defined as barrows of Rostołty type 


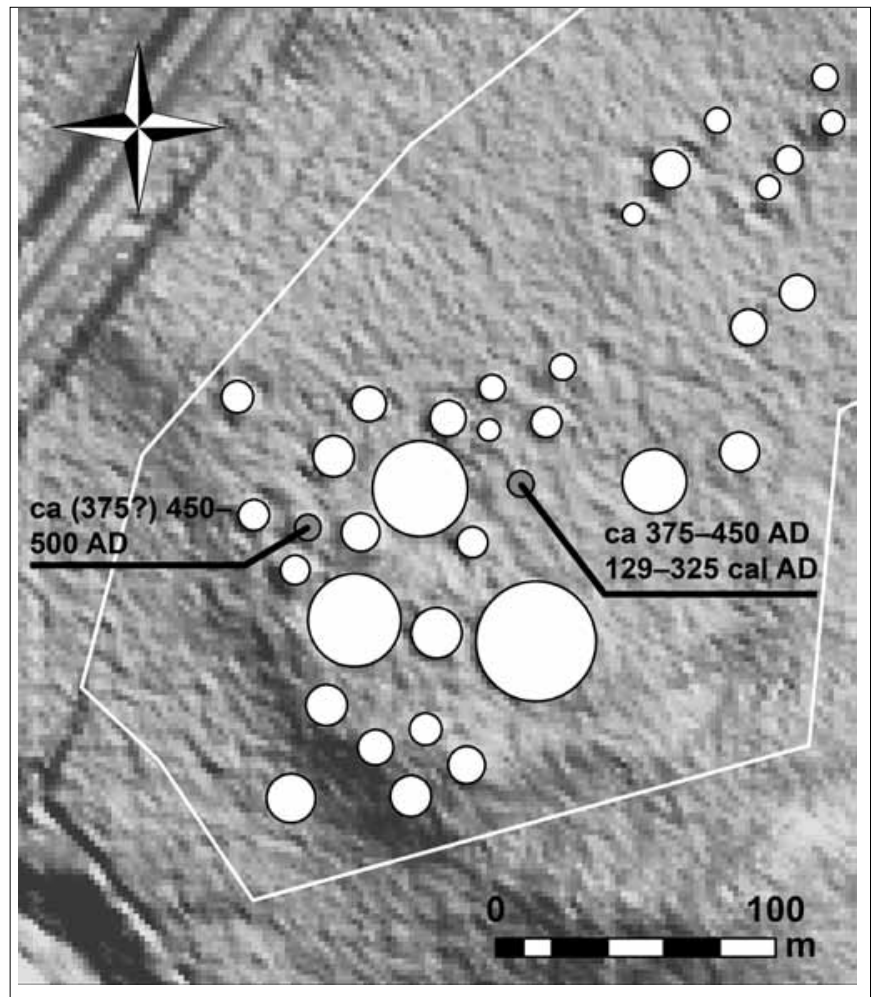

Figure 10. The situation plan and excavated barrows (in grey) in the southwest part of Pavajuonis-Rèkučiai barrow cemetery, and their typological and radiocarbon dating (map by L. Kurila, based on the cemetery plan by Tadas Šidiškis, with spatial corrections made by georeferencing the original plan to the LiDAR image).

(Cieśliński 2014). The radiocarbon date of the PavajuonisRèkučiai burial accords with the idea of the origins of Lithuanian bracelets with thickened terminals from the Kolbenarmringe of the Hassleben-Leuna-Zakrzów horizon (Nowakowski 1999, p. 112). It is, however, much too early to build bridges between East Lithuanian Barrow culture and the Roman period horizon of princely burials of the Barbaricum. This debate remains, hopefully, for the near future.

\section{Some remarks on the social background}

The constantly changing social environment of the restless Migration period caused society's increased demand for means of demonstrating status, including the social symbolism of burial practices. Following the practice in archaeology to relate the most monumental burial structures to the elites, one would presume the barrows discussed to be the burials of top strata. This would seem partially confirmed by excavation data from several other east Lithuanian barrows. In Taurapilis, the 'princely' burial was discovered in the largest barrow $5(13.5 \mathrm{~m})$ (Tautavičius 1981 , p. 20). Similarly, barrow 17 , which contained the burial of an elite warrior, was among the largest ones (15-17 $\mathrm{m}$ ) in Paduobé-Šaltaliūnè III cemetery (Steponaitis 2012, p. 118), and so was the Sudota barrow 3 (30) (14-15 m), in which the cremation of a richly equipped warrior was found (Semenas 2000, p. 198). The same can probably be said about the wealthy Krikštonys male burial found in the remains of a barrow some 16 by 13.5 metres in diameter (Kulikauskas 1959, p. 73). On the other hand, none of these richest barrows even approached in terms of size and shape those discussed in the paper. Moreover, none of the largest mounds ever excavated in east Lithuania contained burials of exceptional richness, for example Baltadvaris barrow 8 (25 m) (Dakanis 2006), Sudota barrows 5 (28) (20x19 m) (Semenas 2002b; 2005a) and 6 (54) (18x17 m) (Semènas 2005b), Kurklių Šilas barrow 13 (40) (17x16 m) (Butènas 2005), Karmazinai barrows 8 (17x16.5 m) and 16 (18x17 m) (Cehak-Hołubowiczowa 1955, pp. 314-315), Dubingiai-Jutonys barrow 62 (16 m) (Šmigelskas et al., 2013), Pučkalaukis barrow 18 (17x16 m) (Jankevičiene 1958, pp. 39-43), Riklikai barrow 7 (16-17 m) (Tautavičius 1969 , p. 43), etc, and not all of them even contained weapons.

Based on the above, we could argue that no direct relation can be observed in East Lithuanian Barrow culture barrow cemeteries between the size of the mound and the status of the deceased, thus challenging the validity of the energy expenditure idea itself. But status is a complex concept, and its images in burials can be various. Grave goods will probably not have exactly the same social implication as the size and complexity of a mortuary structure. That all means of symbolism of high status should necessarily be 
assemblaged within one burial, may appear too stereotypical and straightforward a view. In east Lithuania, too, sets of grave goods and barrow constructions could be used to demonstrate different social dimensions and different social identities.

According to the dual model of social hierarchy in social psychology, an individual may attain and maintain status through either dominance or prestige. These strategies have been used to create, organise and navigate social hierarchies throughout human evolution (Henrich and Gil-White 2001; Cheng et al. 2013; Maner and Case 2016; Redhead 2016; Roberts et al. 2019). High status by dominance invokes power, social superiority, coercion and aggression, while the pathway of achieving status by prestige leads through honour, respect, admiration and recognised skill. Some researchers have also attempted to apply these concepts in archaeology (Ames 2007; Spikins 2008; Plourde 2010). However, markers of dominance and prestige-based status in the mortuary record are so far little discussed.

In a barbarian society, which Migration period east Lithuania was, and which balanced between chiefdom and big-man type social systems (Kurila 2009b, pp. 45-47), status based on dominance and prestige could have partly changed over the course of time, coexisted, and overlapped, and the actual social hierarchy was a combination of both. We can assume that local communities had strategies to symbolically communicate the more complex status of their dead than a pattern of simple bipolar schemes 'high vs low' and 'feared vs valued' (or probably it would be more correct to say that this was decided by society's natural behaviour).

In Balt lands, no extensive custom of giving burial gifts has been observed, and in east Lithuania, even the most abundant assemblages seem like personal belongings rather than gifts. Rich graves thus demonstrate personal or family wealth rather than the community's willingness to award the deceased opulence in the afterlife. In a barbarian society, a chieftain may sustain his authority by dominance built on power, the loyalty of followers, and control, for which wealth and material symbols of prestige are essential while they circulate in the system of gift-giving and reward. On his death, the model of inheritance of social standing will probably decide the degree of the community's involvement in burial. In a dynamic big-man society, however, this social scheme may collapse, and rivalry for new dominance and the redistribution of social powers may occur. Therefore, it should come as no surprise that rich high-status Migration period warriors did not receive funerary treatment which would require exceptional human resources and involvement as compared to commonners. For example, a chieftain was buried in barrow 1 of rather moderate 12-metre size (although surrounded by a large-boulder kerb) in Sudota IV (Šatavičius 2012, pp. 32-33). Another wealthy burial of an armed child in the same mound encourages the assumption that in this case the status inheritance lineage had ceased, and the community was not so focused on elaborate burials.

We cannot know who lies beneath large barrows, or what status those people enjoyed in life. But one thing we can be sure about is that constructions of this size would have mobilised the whole community, and even several, given their small size (Kurila 2014). Basic mathematical calculations show that building a 40-metre barrow would require at least a seven-fold amount of labour than for a 15-metre one, and even more in reality. That all large barrows sit in areas of large concentrations of cemeteries speaks in favour of the inter-community level of their importance. This organisation of people can be achieved by both dominance (compulsion) and prestige (benevolence and respect). The first would signal an advanced inheritance system, in which the ruling family or group maintains the power to organise public labour for funerals in the event of the death of a high-status individual. The second would suggest a specific status, such as a priest (probably somebody similar to Prussian tulissones and ligaschones) or judicial elder (similar to the thungini of the Franks), or prestige acquired through individual qualities, honour, performance and deserts, instead of power, aggression and wealth. The aforementioned excavated mounds of above-average dimensions, but without any expressive manifestation of wealth or power through elaborate grave goods, support the probability of the latter model, of course, not denying the former one.

The proposed hypothesis does not confront the earlier model of the general relations of higher male status to young age, created from a comprehensive database of East Lithuanian Barrow culture barrow cemeteries (Kurila 2009b, pp. 33, 39-40). Very specific mortuary sites are discussed here, and their social implications may well exceed the field in which this model is valid.

The specific shape of some of the large barrows still remains a mystery. It seems to be a relic of an even more impressive initial appearance. On the other hand, other possible explanations can be suggested: massive stones were removed completely at some point in time, or collapsed underground wooden chambers. We can only pin our hopes on future excavations or non-destructive surveys. They may reveal any internal mound structures that would allow us to advance the discussion on their idiosyncratic function, for example, as places for the worship or cult of the dead, calendar observations, or moot, and expand the current image of a burial area as an arena of social process. 


\section{Conclusions}

Although not all have eloquent exteriors (ditch and bank structures), the large barrows discussed here are distinguished among East Lithuanian Barrow culture barrow cemeteries by their size and shape. So far, 11 barrows clearly matching this definition are known in six cemeteries. Their location in cemetery concentrations encourages their interpretation as a sort of 'centre' in terms of burial and probably social life or cults.

The large barrows can be dated only by referring to the remains of stone kerbs, their setting in the cemeteries, and the excavation data from the surrounding mounds, including both typological and radiocarbon dates. This data altogether points to the Migration period, supposedly to a fairly short timespan in the 5 th century, a period during which barrows assumed special social dimensions.

Following the idea of the energy expenditure in burials, that is, the amount of labour consumed in building them, large barrows should be viewed as an expression of the exceptional social status of those interred in them. This, however, does not necessarily mean power and military attribution. The dual model of social hierarchy in social psychology states that status may be attained through either dominance or prestige. Both can determine the mourners' behaviour in terms of the effort put into the burial, but for very different reasons. Dominance-based status will require advanced social inheritance, while a prestige-based one will signal specific social roles or personal achievement. Large barrows can be a reflection of either of those.

In Migration period society, which lived under conditions of turbulent change, and was ruled by harsh social norms, power and achievement were, of course, much more interrelated than in modern society. Prowess in battle was the main prerequisite for prestige. However, other social dimensions, including legal and ceremonial roles, or female social identities, could also have deserved a high-status burial. The model suggested here emphasises that highstatus large barrows should not implicitly be considered to be the tombs of the supreme ruling strata.

\section{Abbreviations}

Arch. Baltica - Archaeologia Baltica

Arch. Lituana - Archaeologia Lituana

ATL - Archeologiniai tyrinejjimai Lietuvoje ... metais. Vilnius (since 1967)

FA - Fennoscandia Archaeologica
Hundred Years - G. Zabiela, Z. Baubonis, and E. Marcinkevičiūtè, eds. A Hundred Years of Archaeological Discoveries in Lithuania. Vilnius: Lithuanian Archaeology Society

Lietuvos Arch. - Lietuvos archeologija

MAD’A - Lietuvos TSR Mokslų akademijos darbai, serija A

WA - Wiadomości Archeologiczne

\section{References}

\section{Manuscripts}

Kashirskii, V., 1907. O raskopkakh" V. A. Kashirskago v" Sventsianskom" uezde Vilenskoi gub. Unpublished excavations report. Archive of the Institute for the History of Material Culture, Russian Academy of Sciences, St Petersburg, F. 1, No. 53/1907.

Tautavichius, A., 1953. Vostochnaia Litva v pervom tysiacheletii nasher erry. Unpublished thesis (PhD). Lithuanian Institute of History and Law. Institute of Lithunian History, Archive, corpus 2, file No. 2.

Tautavičius A., 1969. Riklikų, Anykščiu raj. pilkapiu 1969 m. tyrinejjimy ataskaita ir radiniu sąrašas. Unpublished excavations report. Institute of Lithunian History, Archive, corpus 1, file No. 257.

Valstybès, 1935. Valstybès archeologijos komisijos medžiaga [Materials of the State Archaeological Commission]. Library of the Cultural Heritage Centre, corpus 1, inventory 1, file No. 101, pp. 244-256.

\section{Literature}

Ames, K.M., 2007. The Archaeology of Rank. In: R.A. Bentley, H.D.G. Maschner and C. Chippendale, eds. Handbook of Archaeological Theories. Lanham: AltaMira Press, 487-513.

Bitner-Wróblewska, A., 2010. North-eastern Poland in first centuries $A D-a$ world apart. In: U. Lund Hansen and A. BitnerWróblewska, eds. Worlds Apart? Contacts across the Baltic Sea in the Iron Age, Network Denmark-Poland, 2005-2008. København, Warszawa: Det Kongelige Nordiske Oldskriftselskab, Państwowe muzeum archeologiczne, 141-184.

Bliujienè, A. 2006. Watershed between Eastern and Western Lithuania during the Early and Late Migration Period. Arch. Lituana, 7, 123-143.

Bliujienè, A., 2013. Armed People of East and Southeast Lithuania in the Geocultural Context of the Migration Period. Arch. Baltica, 19, 145-165.

Bliujienė, A., 2016. South Lithuanian Barrows. In: Hundred Years, 208-225.

Bliujienè, A. and Curta, F., 2011. Exotic Lands, Quixotic Friends: Eastern Lithuania and the Carpathian Basin in Late Antiquity and the Early Middle Ages (AD c 380 to c 620). Medieval Archaeology, 55, 29-65, https://doi.org/10.1179/17458171 1 X13103897378366.

Bliujiene, A. and Steponaitis, V., 2009. Wealthy Horsemen in the Remote and Tenebrous Forests of East Lithuania during the Migration Period. Arch. Baltica, 11, 185-205.

Bliujienè, A., Steponaitis, V., Šatavičius, E., Grižas, G., 2016. Concentration of Authority and Power in East Lithuania, between Tauragnas Lake and the Middle Reaches of the Žeimena River, during the Migration Period. Estonian Journal of Archaeology, 21 (2), 117-147, https://doi.org/10.3176/arch.2017.2.02. 
Brown, J.A., 1981. The search of rank in prehistoric burials. In: R. Chapman, I. Kinnes and K. Randsborg, eds. The archaeology of death. Cambridge University Press, 25-37.

Butenas, E., 2006. Kurklių šilo pilkapynas. In: ATL 2005 metais. Vilnius: Society of the Lithuanian Archaeology, 85-86.

Carr, C., 1995. Mortuary Practices: Their Social, PhilosophicalReligious, Circumstantial, and Physical Determinants. Journal of Archaeological Method and Theory, 2 (2), 105-200, https:// doi.org/10.1007/BF02228990.

Carver, M., 1998. Sutton Hoo: Burial Ground of Kings? Philadelphia: University of Pennsylvania Press.

Cehak-Hołubowiczowa, H., 1955. Cmentarzysko kurhanowe z VI i VII w. w miejsc. Karmazyny koło miasta Troki w Litewskiej SRR. WA, 22 (3-4), 312-331.

Cheng, J.T., Tracy, J.L., Foulsham, T., Kingstone, A. and Henrich, J., 2013. Two Ways to the Top: Evidence That Dominance and Prestige are Distinct Yet Viable Avenues to Social Rank and Influence. Journal of Personality and Social Psychology, 104 (1), 103-125, https://doi.org/10.1037/a0030398.

Cieśliński, A., 2014. Kopce kultury wielbarskiej z Mazowsza i Podlasia a tzw. typ rostołcki - próba nowego spojrzenia na związki cmentarzysk kurhanowych z północnej i wschodniej Polski. WA, LXV, 45-93.

Dakanis, B., 2006. Baltadvario pilkapynas. In: ATL 2004 metais. Vilnius: Society of the Lithuanian Archaeology, 71-73.

Girininkas, A., 2007. A Defence Installation of the Developing Lithuanian State. Arch. Baltica, 8, 347-359.

Grinsell, I.V., 1953. The Ancient Burial-mounds of England, 2nd ed. London: Methuen.

Henrich, J. and Gil-White, F.J., 2001. The evolution of prestige: Freely conferred deference as a mechanism for enhancing the benefits of cultural transmission. Evolution and Human Behavior, 22 (3), 165-196, https://doi.org/10.1016/S10905138(00)00071-4.

Jankevičienè, A., 1958. Počkaluvkos pilkapiai. MADA, 2 (5), 39-43.

Johnson, N., 2015. From Malvern to the Irish Sea: Early Bronze Age round barrows in a border landscape. Thesis (PhD). University of Worcester.

Kaczyński, M., 1963. Materiały z badań 1934 r. na cmentarzysku kurhanowym w miejscowości Sudata, pow. Święciany, na Wileńszczyźnie (LSRR). WA, XXIX (2), 138-156.

Kulikauskas, P., 1959. Naujas archeologinis paminklas Užnemunèje (V-VII amžių jotvingių senkapis Krikštonyse, Lazdijų raj.). $M A D^{\prime} A, 1$ (6), 71-88.

Kuncevičius, A., Laužikas, R., Šmigelskas, R. and Augustinavičius, R., 2012. Dubingių istoriné žemė - Rytų Lietuvos pilkapių kultūros ar lietuvių pilkapių teritorija? Lituanistica, 1 (87), 12-35.

Kurila, L., 2009a. Socialinis statusas ir lytis: Geležies amžiaus Rytų Lietuvos socialinès organizacijos analizè. Lietuvos Arch., 35, 153-192.

Kurila, L. 2009b. The Social Organisation in East Lithuania in the $3^{\text {rd }}-12^{\text {th }}$ Centuries (on the Basis of the Mortuary Record). Summary of Thesis (PhD). Vilnius University.

Kurila, L., 2011. Vladimiro Kaširskio kasinèjimai Vajuonio ir Žeimenio tarpežerio pilkapynuose 1906 ir 1907 m. In: A. Luchtanas and L. Tamulynas, eds. Lietuvos archeologijos šaltiniai Sankt Peterburge. Vilniaus universitetas, 101-174.

Kurila, L., 2014. Apgyvendinimo tankumas geležies amžiaus Lietuvoje: Žeimenos baseino mikroregionas. Lietuvos Arch., 40, 181-204.

Kurila, L., 2015. Žmonių kaulų iš Rytų Lietuvos pilkapių AMS ${ }^{14} \mathrm{C}$ datavimas: rezultatai, perspektyvos. Lietuvos Arch., 41, 45-80.
Kurila, L., 2016. East Lithuanian Barrows - Burial in the Cradle of Lithuanian Tribes In: Hundred Years, 192-207.

Lau, N., 2014. Kammergrab und Gräberfeld von Pilgramsdorf (Pielgrzymowo) - Ein Fundplatz zwischen kulturellem Kontext und überregionalen Einflüssen. In: A. Abegg-Wigg and N. Lau, eds. Kammergräber im Barbaricum. Zu einflüssen und Übergangsphänomenen von der vorrömischen Eisenzeit bis in die Völkerwanderungszeit. Internationale Tagung, Schleswig 25.-27. November 2010. Neumünster: Wachholtz, 199-228.

Lebedev, G., 1994. Slavs and Finns in Northwest Russia Revisited. FA, XI, 89-95.

Ligi, P., 1993. National Romanticism in Archaeology: The Paradigm of Slavonic Colonization in North-West Russia. FA, X, 31-39.

Luchtanas, A., 2002. Grabijolų (Žemaitiškių) pilkapynas II. In: ATL 2001 metais. Vilnius: Diemedžio leidykla, 92-93.

Luchtanas, A., 2005a. Grabijolu (Žemaitiškių) pilkapynas II. In: ATL 2002 metais. Vilnius: Diemedžio leidykla, 72.

Luchtanas, A., 2005b. Grabijolų (Žemaitiškių) pilkapynas II. In: ATL 2003 metais. Vilnius: Diemedžio leidykla, 94-95.

Luchtanas, A., 2006. Grabijolų (Žemaitiškių) pilkapynas II. In: ATL 2004 metais. Vilnius: Society of the Lithuanian Archaeology, 83-84.

Maner, J.K. and Case, C.R., 2016. Dominance and Prestige: Dual Strategies for Navigating Social Hierarchies. Advances in Experimental Social Psychology, 54, 129-180, https://doi. org/10.1016/bs.aesp.2016.02.001.

Merkevičius, A., 1990. Sudotos pilkapių tyrinèjimai. In: ATL 1988 ir 1989 metais. Vilnius: Lietuvos istorijos institutas, 52-56.

Merkevičius, A., 2016. West Lithuania during the Early Metal Age. In: Hundred Years, 130-147.

Michelbertas, M., 2016. Samogitian and North Lithuanian Barrows. In: Hundred Years, 286-301.

Nowakowski, W., 1999. Das Problem der Chronologie der spätrömischen Kaiserzeit und Völkerwanderungszeit im Memelgebiet hinsichtlich der Funde aus dem Gräberfeld Aukštakiemiai (Oberhof). Arch. Lituana, 1, 110-118.

Plourde, A.M., 2010. Human Power and Prestige Systems. In: P.M. Kappeler and J.B. Silk, eds. Mind the Gap: Tracing the Origins of Human Universals. Heidelberg, Dordrecht, London, New York: Springer, 139-152.

Pokrovskii, F.V., 1895. Kurgany na granice sovremennoi Litvy i Belorusi. In: P. Uvarova and S.S. Sluckii, eds. Trudy deviatago arkheologicheskago s"ezda v"Vil'ne 1893, I. Moskva: Tipografiia Ė. Lisnera i Iu. Romana, 166-220.

Pronin, G.N., 1981. Sopki, kurgany, zhal'niki (k voprosu preemstvennosti). Kratkie soobshcheniia Instituta arkheologii, 166, $11-16$.

Radiņš, A., 1999. 10.-13. gadsimta senkapi latgal̦u apdzīvotajā teritorijā un Austrumlatvijas etniskās, sociālās un politiskās vēstures jautājumi. In: Latvijas Vēstures muzeja raksti, 5. Rīga: N.I.M.S.

Randsborg, K., Merkyte, I., Merkevičius, A. and Kulakov, V.I., 2016. Kaup 2014: Archaeological Excavations \& Research History. Acta Archaeologica, 87 (1), 85-130, https://doi. org/10.1111/j.1600-0390.2016.12168.x.

Redhead, D.J., 2016. Social Hierarchy \& Social Networks: The Effects of Prestige and Dominance within a Developmental Context. Thesis (PhD). Durham University.

Roberts, A., Palermo, R. and Visser, T.A.W., 2019. Effects of dominance and prestige based social status on competition for attentional resources. Scientific Reports, 9, 1-11, https://doi. org/10.1038/s41598-019-39223-0.

Rybakov, B.A., 1949. Drevnosti Chernigova. Materialy i issledovaniia po arkheologii SSSR, 11, 14-53. 
Schulze-Dörrlamm, M., 1986. Romanisch oder Germanisch? Untersuchungen zu den Armbrust- und Bügelknopffibeln des 5. und 6. Jahrhunderts n. Chr. aus den Gebieten westlich des Rheins und südlich der Donau. In: Jahrbuch des Römisch-Germanischen Zentralmuseums Mainz, 33 (2), 593-720.

Schuster, J., 2010. Lübsow - Älterkaiserzeitliche Fürstengräber im nördlichen Mitteleuropa. In: J. von Bemmann, U. Brosseder and H.-E. Joachim, eds. Bonner Beiträge zur vor- und frühgeschichtlichen Archäologie, 12. Vor- und Frühgeschichtliche Archäologierheinische Friedrich-Wilhelms-Universität Bonn.

Semènas, V., 1996. Pavajuonio-Rèkučių pilkapyno tyrinèjimai 1994 metais. In: ATL 1994 ir 1995 metais. Vilnius: Lietuvos istorijos institutas, 85 .

Semènas, V., 1998. Pavajuonio-Rèkučiu pilkapyno tyrinèjimai 1996 metais. In: ATL 1996 ir 1997 metais. Vilnius: Lietuvos istorijos institutas, $150-152$.

Semėnas, V., 2000. Sudatos I-osios pilkapių grupès tyrinèjimai. In: ATL 1998 ir 1999 metais. Vilnius: Diemedžio leidykla, 197-199.

Semėnas, V., 2002a. Sudotos I-asis pilkapynas. In: ATL 2000 metais. Vilnius: Diemedžio leidykla, 73-74.

Semènas, V., 2002b. Sudotos pilkapynas I. In: ATL 2001 metais. Vilnius: Diemedžio leidykla, 93.

Semènas, V., 2005a. Sudotos I pilkapynas. In: ATL 2002 metais. Vilnius: Diemedžio leidykla, 73-74.

Semènas, V., 2005b. Sudotos pilkapynas I. In: ATL 2003 metais. Vilnius: Diemedžio leidykla, 94-95.

Semenas, V., 2006. Sudotos pilkapynas I. In: ATL 2004 metais. Vilnius: Society of the Lithuanian Archaeology, 86-87.

Spikins, P., 2008. 'The Bashful and the Boastful': Prestigious Leaders and Social Change in Mesolithic Societies. Journal of World Prehistory, 21 (3-4), 173-193, http://dx.doi. org/10.1007/s10963-008-9015-x.

Steponaitis, V., 2012. Paduobè - Šaltaliūnè Barrow Cemetery III. In: Hundred Years, 114-121.

Šatavičius, E., 2012. The investigation of the Sudota Archaeological Complex. In: Hundred Years, 27-34.

Šmigelskas, R., Augustinavičius, R., Kuncevičius, A. and Laužikas, R., 2013. Jutonių, Dubingių pilkapynas. In: ATL 2012 metais. Vilnius: Society of the Lithuanian Archaeology, 149-153.

Tainter, J.A. 1978. Mortuary Practices and the Study of Prehistoric Social Systems. In: M.B. Schiffer, ed. Advances in Archaeological Method and Theory, I. New York: Academic Press, 105-141.

Tautavičius, A., 1981. Taurapilio „kunigaikščio“ kapas. Lietuvos Arch., 2, 18-43.

Tvauri, A., 2007. Migrants or Natives? The Research History of Long Barrows in Russia and Estonia in the $5^{\text {th }}-10^{\text {th }}$ Centuries. In: J. Nuorluoto, ed. Topics on the Ethnic, Linguistic and Cultural Making of the Russian North. Slavica Helsingiensia, 32. University of Helsinki, 247-285.

Tyszkiewicz, E., 1850. Badania archeologiczne nad zabytkami przedmiotów sztuki, rzemiost i t. d. $w$ dawniej Litwie i Rusi Litewskiej. Wilno: Nakładem i drukiem Józefa Zawadzkiego.

Vaitkevičius, V., 2006. Senosios Lietuvos šventvietès: Aukštaitija. Vilnius: Diemedžio leidykla.

Vasks, A., 2001. Agrais dzelzs laikmets. 1.-400. g. In: $\bar{E}$. Mugurēvičs and A. Vasks, eds. Latvijas senākā vēsture. Rīga: Latvijas vēstures institūta apgāds, 186-231.

Wason, P.K., 1994. The archaeology of rank. Cambridge University Press.

Zabiela, G., 1992. Nalšia Lietuvos valstybès kūrimosi išvakarèse. In: K. Garšva, N. Laurinkienė, V. Milius and M. Tamošiūnas, eds. Rytu Lietuva: Istorija, kultūra, kalba. Vilnius: Mokslas, 12-24.
Zabiela, G., 1996. Archeologas Vladimiras Kaširskis. Muziejai ir paminklai, 3, 41-52.

\section{DIDIEJI PILKAPIAI \\ RYTU LIETUVOJE - \\ NEATSKLEISTA PASLAPTIS}

\section{LAURYNAS KURILA}

\section{Santrauka}

Rytų Lietuvos pilkapynų, kuriuose sampilų dydžių ir formų ịvairovė nėra ženkli, kontekste išsiskiria didieji pilkapiai. Tai neiprastai didelio skersmens (iki 37-41 m) ir nebūdingo žemos trapecijos pavidalo skerspjūvyje sampilai, kai kurie jų yra sudètingesnès struktūros - apskritos pylimèlių, griovių ir duobių konstrukcijos.

Iki šiol žinoma 11 sampilų (1, 2 pav.), matmenimis ir forma atitinkančių didžiojo pilkapio apibrèžimą: po vieną Dailidžių-Ardiškio II (3 pav.), Grabijolų-Žemaitiškių II (4 pav.), Liūlinès II (5 pav.) ir Paduobès-Šaltaliūnès III (7 pav.), bent trys - Sudotos (6 pav.) ir keturi - Pavajuonio-Rèkučių (8 pav.) pilkapynuose. Visi šie laidojimo paminklai yra išsidèstę didesnèse pilkapynų grupèse: du pirmieji - palei dešinijji Neries krantą, likusieji - Žeimenos kairiojo kranto ir ị šiaurę nuo jos ištakų plytinčio ežeryno regione. Tai leidžia manyti, jog didieji pilkapiai galèjo būti laidojimo vietos, svarbios regioniniu, aukštesniu nei vienos bendruomenès lygmeniu.

Nè vienas didysis pilkapis nèra tyrinètas, todèl tiesiogiai jie nedatuoti. Tačiau pagal akmenų vainikų liekanas, pilkapių išsidèstymą gretimų sampilų atžvilgiu ir pastaruosiuose aptiktų kapų tipologines bei radiokarbonines datas $(9,10$ pav.) juos galima netiesiogiai gana patikimai datuoti tautų kraustymosi laikotarpiu, tikètinai $\mathrm{V}$ a. - periodu, kai laidosena tapo ypač svarbia statuso išraiškos priemone.

Pilkapių pylimui įdètos didelès pastangos rodo ypatingą laidotuvių dalyvių santyki su mirusiuoju. Remiantis išeikvotos energijos modeliu, galima teigti, kad tai atskleidžia išskirtinị laidojamo asmens statusą ir tvirtą bendruomenès nuostatą jị išreikšti simbolinėmis priemonèmis.

Kita vertus, nei turtingiausių kapų, nei didžiausių pilkapių kituose Rytų Lietuvos pilkapynuose tyrimų rezultatai nerodo aiškaus ryšio tarp sampilo dydžio, taigi ir bendruomenès įsitraukimo ị laidotuvių ceremoniją, ir aukšto statuso ar kario atributų, kiek juos simbolizuoja ịkapių kompleksai. Reikia manyti, pilkapio konstrukcija ir ikapès atskleidžia kiek skirtingus socialinius identitetus ir statuso aspektus. Didelès darbo sąnaudos pilkapio pylimui nebūtinai indikuoja karių ar valdančiojo elito kapus. 
Socialineje psichologijoje pasiūlytas dvilypis socialinès hierarchijos modelis teigia, jog statusas gali būti igyjamas dominavimu (galia, viršenybe, agresija) arba prestižu (asmeninemis savybèmis, pasiekimais, pagarba ir pripažinimu). Laidosenoje dominavimu paremtas statusas, tikètina, atsispindèdavo gausiomis ịkapèmis, pabrèžiančiomis asmeninį turtą, kuris elitui padèjo igyti ir išlaikyti šalininkų lojalumą ir galią. Tačiau lyderio mirties atveju bendruomenès pastangos eikvoti energiją laidotuvèms priklausè nuo statuso paveldimumo sistemos išsivystymo lygio, nutrūkus paveldejimo linijai tokios motyvacijos galèdavo nelikti. Tuo tarpu prestižu paremtas statusas arba specifiniai socialiniai vaidmenys (pvz., žynio ar sueigos seniūno) veikiau būtų pabrèžiami sudètingesniais, didesnių pastangų reikalaujančiais laidojimo ritualais. Žinoma, barbariškoje tautų kraustymosi laikotarpio visuomenejje, atšiaurioje ir dinamiškoje socialinëje aplinkoje, balansuojančioje tarp vadystės ir didžiojo žmogaus sistemų, šios statuso dimensijos buvo susipynusios. 